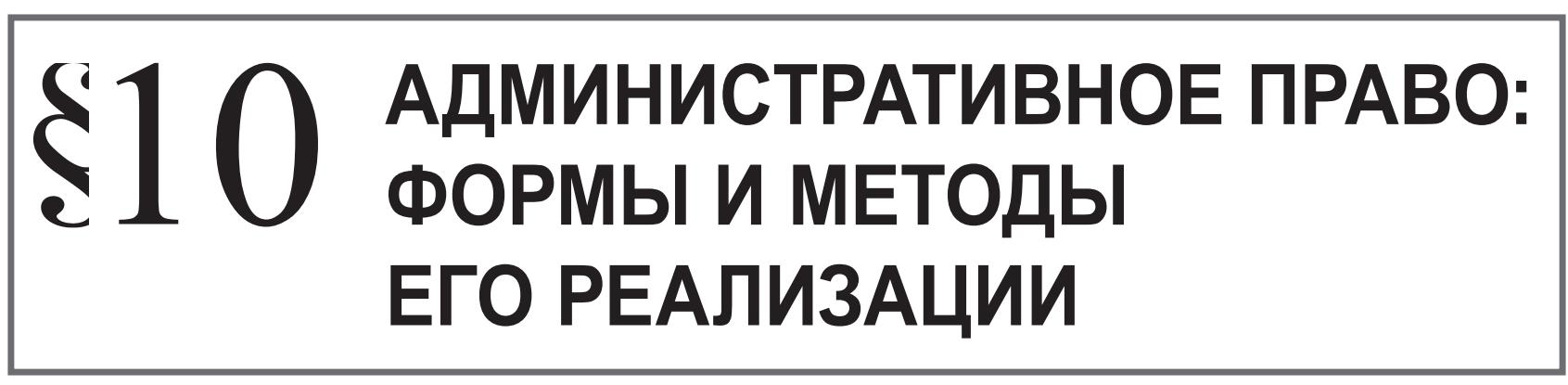

\title{
ПЕРЕДАЧА ГОСУДАРСТВЕННОГО И МУНИЦИПАЛЬНОГО ИМУЩЕСТВА В ХОЗЯЙСТВЕННОЕ ВЕДЕНИЕ, И ОПЕРАТИВНОЕ УПРАВЛЕНИЕ КАК ОСОБЫЙ ВИД АДМИНИСТРАТИВНОГО ДОГОВОРА
}

$\mathrm{B}$ настоящее время важнейшим способом управления имуществом публично-правовых образований остается передача юридическим лицам, созданным собственником — публично-правовыми образованиями, этого имущества на праве хозяйственного ведения и на праве оперативного управления. В девяностые годы двадцатого века право хозяйственного ведения и право оперативного управления многие специалисты называли временными, нежизнеспособными, переходными, наследием социалистической экономики. Однако по-прежнему государственным и муниципальным предприятиям и учреждениям для выполнения ими определенных функций передается имущество публично-правовых образований, включая федеральные энергетические системы, территории государственных природных заповедников, музейные предметы и музейные коллекции, не в собственность и не в аренду. Количество государственных и муниципальных предприятий и учреждений с девяностых годов двадцатого века не сокращается, а напротив растет. Так в 1996 г. в среднестатистическом районе Московской области (Мытищинском районе) насчитывалось 59 муниципальных предприятий и учреждений, в 2012 г. - в два раза больше (112 предприятий и учреждений расположены в Красногорском районе Московской области). Их правовой статус в настоящее время регулируется не только Гражданским кодексом, но и специальными федеральными законами и множеством подзаконных актов. Отношения публичной собственности продолжают динамично развиваться. Учитывая особую ценность государственного и муниципального имущества, вопрос о правовом регулиро- вании этих отношений не теряет своей актуальности. В этой связи важным представляется вопрос и о правовой природе договоров (актов) о передаче государственного и муниципального имущества в хозяйственное ведение и оперативное управление.

Понятие «право оперативного управления» в отечественном законодательстве появляется еще в Гражданском кодексе РСФСР, утвержденном Верховным Советом РСФСР 11.06.1964 г. В соответствии со ст. 94 ГК РСФСР государственное имущество, закрепленное за государственными организациями, состоит в оперативном управлении этих организаций, осуществляющих в пределах, установленных законом, в соответствии с целями их деятельности, плановыми заданиями и назначением имущества, права владения, пользования и распоряжения имуществом. Содержание данного права практически не раскрывается. Очевидно, что права государственных организаций в отношении закрепленного за ними имущества весьма ограничены.

В ст. 26 Закона о собственности в СССР № 1305-1, принятом Верховным Советом СССР 6 марта 1990 г., указано, что имущество, являющееся государственной собственностью и закрепленное собственниками за государственным учреждением (организацией), состоящем на государственном бюджете, находится в оперативном управлении этого учреждения (организации); государственные учреждения (организации), которые могут в предусмотренных законодательством случаях осуществлять хозяйственную деятельность, приобретают право на самостоятельное распоряжение доходами от такой деятельности и имуществом, приобретен- 
ном за счет этих доходов. При этом государственные учреждения (организации) отвечают по своим обязательствам находящимися в их распоряжении денежными средствами. И только при недостаточности у государственного учреждения (организации) денежных средств ответственность по его обязательствам несет собственник соответствующего имущества.

Институт права полного хозяйственного ведения законодательно закрепляется в ст. 24 Закона о собственности в СССР, в соответствии с которой государственное предприятие, осуществляя право полного хозяйственного ведения своим имуществом, владеет, пользуется и распоряжается указанным имуществом и по своему усмотрению совершает в отношении этого имущества любые действия, не противоречащие закону. Государственные органы, уполномоченные управлять государственным имуществом, решают вопросы создания предприятия, определения целей его деятельности, его реорганизации и ликвидации, осуществляют контроль за эффективностью использования и сохранности вверенного ему государственного имущества. В случае принятия государственным органом, уполномоченным управлять государственным имуществом, решения о реорганизации и ликвидации государственного предприятия, кроме случаев, когда оно признано несостоятельным (банкротом), трудовой коллектив вправе потребовать передачи предприятия в аренду или преобразования его в иное предприятие, основанное на коллективной собственности.

Статья 5 Закона о собственности в РСФСР № 4431 от 24.12.90 г. относит право полного хозяйственного ведения и оперативного управления к вещным правам. При этом указано, что собственник вправе закрепить принадлежащее ему имущество за созданным им предприятием на праве полного хозяйственного ведения, а имущество, закрепленное собственником за государственными и иными учреждениями, финансируемыми за счет средств собственника, находится в оперативном управлении этого учреждения. Не ясно, только ли за государственными предприятиями закрепляется имущество на праве полного хозяйственного ведения и оперативного управления. В статье 24 Закона о собственности в РСФСР говорится уже о наделении государственным и муниципальным имуществом не только государственных, но и муниципальных предприятий и учреждений. Появляются понятия муниципального имущества, муниципальных предприятий и учреждений.

В ст. 6 Закона РСФСР «О предприятиях и предпринимательской деятельности» от 25 декабря 1990 г. № 445-1, указано, что государственное предприятие учреждается органами управления РСФСР, входящих в ее состав республик, автономных областей, автономных округов, краев и областей, уполномоченными управлять государственным имуществом. Данное имущество может передаваться в хозяйственное ведение предприятию в лице трудового коллектива.

Таким образом, несмотря на незначительные различия положений законодательства и некоторую неопределенность сферы применения правоотношений хозяйственного ведения и оперативного управления, к 1991 г. ХХ в. содержание права хозяйственного ведения и оперативного управления было законодательно определено и широко применялось на практике уже в новых экономических условиях.

Гражданский кодекс РФ, принятый Государственной Думой 21 октября 1994 г., относит право хозяйственного ведения и право оперативного управления наряду с правом собственности к вещным правам.

В соответствии со ст. 295 Гражданского кодекса РФ, собственник имущества, переданного в хозяйственное ведение предприятию, решает вопросы создания предприятия, определения предмета и целей его деятельности, реорганизации и ликвидации предприятия, назначает руководителя предприятия, осуществляет контроль за использованием по назначению и сохранностью переданного предприятию имущества.

В соответствии со ст. 296 Гражданского кодекса РФ собственник имущества, переданного в оперативное управление учреждению и казенному предприятию, вправе изъять излишнее, неиспользуемое или используемое не по назначению имущество, решает вопросы создания предприятия, определения предмета и целей его деятельности, реорганизации и ликвидации предприятия, назначает руководителя предприятия, осуществляет контроль за использованием по назначению и сохранностью переданного имущества.

Положения ГК РФ о праве хозяйственного ведения и праве оперативного управления получили дальнейшее развитие в Федеральном законе от 12 января 1996 г. № 7-Ф3 «О некоммерческих организациях», Федеральном законе от 14 ноября 2002 г. № 161-Ф3 «О государственных и муниципальных унитарных предприятиях», Федеральном законе от 30 ноября 2006 г. № 174-Ф3 «Об автономных учреждениях».

Как мы видим, содержание права хозяйственного ведения практически не изменилось с 1990 г., хотя в ГК РФ и особенно в ФЗ «О государственных и муниципальных унитарных предприятиях» раскрыто, расширено и уточнено содержание прав собственника имущества предприятия и прав предприятия. Например, в ГК РФ закреплено право собственника назначать руководителя предприятия; в ФЗ «О государственных и 
муниципальных унитарных предприятиях» - давать согласие на участие унитарного предприятия в ассоциациях и других объединениях коммерческих организаций, определять порядок составления, утверждения и установления показателей планов финансово-хозяйственной деятельности унитарного предприятия, согласовывать прием на работу главного бухгалтера, заключение, изменение и прекращение трудового договора с ним, утверждать бухгалтерскую отчетность и отчеты унитарного предприятия, давать согласие на распоряжение недвижимым имуществом, давать согласие на создание филиалов и открытие представительств унитарного предприятия, давать согласие на участие унитарного предприятия в других юридических лицах, принимать решения о проведении аудиторских проверок, утверждать кандидатуру аудитора и определять размер оплаты его услуг.

Таким образом, институт права хозяйственного ведения и оперативного управления получил не только законодательное развитие. Расширилась область его практического применения.

При анализе содержания права хозяйственного ведения и оперативного управления на основании положений ГК РФ, Ф3 «О государственных и муниципальных унитарных предприятиях», Федерального закона от 29 декабря 1994 г. № 78-ФЗ «О библиотечном деле», Федерального закона от 15 февраля 1995 .а № 33-Ф3 «Об особо охраняемых природных территориях», Федерального закона от 26 мая 1996 г. № 54-Ф3 «О музейном фонде Российской Федерации и музеях в Российской Федерации», текстов договоров (актов) о передаче имущества на праве хозяйственного ведения и оперативного управления возникают сомнения в обоснованности отнесения права хозяйственного ведения и права оперативного управления к вещным правам.

Е.А. Суханов справедливо полагает, что право оперативного управления, в 60-е годы XX в., законодатель не относит к вещным правам не только по причине отсутствия в то время категории «вещные права», но и в связи с тем, что «в действительности ни право оперативного управления, ни его последующий аналог в виде «права хозяйственного ведения» не являются вещными правами в классическом понимании этого термина. Они не обеспечивают экономически необходимое участие одного лица в праве собственности на недвижимость другого лица, а представляют собой правовую форму реализации государственной собственности в условиях плановой экономики» ${ }^{1}$.

1 См.: Суханов Е.А. О понятии и видах вещных прав в российском гражданском праве // Журнал российского права. 2006. - № 12. - C. 42.
В условиях рыночной экономики и при отнесении права хозяйственного ведения и права оперативного управления Гражданским кодексом Российской Федерации к вещным правам совершенно очевидно их особое положение среди других видов имущественных прав. Анахронизмом эти права так и не стали. Напротив - они до сих пор широко применяются, право хозяйственного ведения и право оперативного управления на недвижимое имущество подлежат государственной регистрации, защите этих прав отведено особое место и в науке, и в судебной практике 2 . При этом договоры (акты) о передаче имущества на праве хозяйственного ведения и оперативного управления обладают только им присущими особенностями и не носят исключительно гражданско-правового характера. По своему правовому смыслу такие договоры являются скорее административными.

В российском законодательстве до сих пор отсутствует понятие административного договора. Наука административного права изучает правовую природу административного договора и классифицирует административные договоры, в частности, разделяет административные договоры на нормативные и индивидуальные. Советское административное право рассматривало административные договоры с 20-х гг. $\mathrm{XX}$ в. как одну из форм управленческой деятельности $^{3}$. В 60 -е гг. теория административного договора получает свое развитие в связи с принятием Основ гражданского законодательства Союза ССР и союзных республик, утв. Законом СССР от 08.12.1961 г. и Гражданского кодекса РСФСР, утвержденного Верховным Советом РСФСР 11.06.1964 г. В те годы административный договор рассматривался не только как форма управленческой деятельности, но и как соглашение, хотя признавалось фактическое неравноправное положение его сторон ${ }^{4}$. В 90-е годы в изменившихся условиях усиливается роль договорного регулирования в различных сферах общественных отношений, кардинально меняются функции государственного управления, и сама исполнительная власть становится иной. Дальнейшее развитие получает институт административного договора. Появляются новые определения административного договора, которые условно можно

\footnotetext{
2 См.: Пп. 5-10 Постановления Пленума Верховного Суда РФ №10, Пленума Высшего Арбитражного Суда №22 от 29.04.2010. О некоторых вопросах, возникающих в судебной практике при разрешении споров, связанных с защитой права собственности и других вещных прав.

См.: Сперанская К. Об административном договоре // Вестник Верховного Суда СССР. - 1928. - № 3 (12).

4 См.: Новоселов В.И. К вопросу об административных договорах // Правоведение. - 1969. - № 3.
} 
разделить на две группы: административный договор как правовой акт и административный договор как соглашение. Д.Н. Бахрах определяет административный договор как основанный на административно-правовых нормах и выработанный в публичных интересах в результате добровольного согласования воли двух (или более) субъектов административного права, одним из которых всегда выступает субъект административного права, многосторонний акт, устанавливающий (прекращающий, изменяющий) права и обязанности его участников ${ }^{5}$. А.А. Абдурахманов, А.В. Демин, А.П. Коренев, определяют административный договор как основанное на нормах административного права соглашение между двумя или более формально равными субъектами, имеющее своим предметом совершение управленческих либо организационных действий, в котором хотя бы одна из сторон является органом государственного управления либо его законным представителем ${ }^{6}$.

Важнейшей функцией, присущей индивидуальному административному договору является правореализационная функция. В результате заключения административного договора происходит воплощение норм административного права в субъективные права и обязанности ${ }^{7}$.

Среди других функций административного договора следует отметить регулятивную функцию. Посредством административного договора устанавливаются определенные правила поведения для сторон, т.е. административный договор является регулятором общественных отношений. Для договоров передачи имущества в хозяйственное ведение и оперативное управление особое значение имеет и обеспечительная функция, которая состоит в обеспечении особо значимых (публичных) интересов и конкретных интересов участников административного договора.

Существуют различные мнения относительно юридических признаков административного договора, но тот факт, что административный договор является разновидностью публично-правового договора сомнений обычно не вызывает ${ }^{8}$. Одной из сторон административного договора является государство в лице сво-

\footnotetext{
5 См.: Бахрах Д.Н. Административные договоры // Административное право России. - М., 2002.

6 См.: Абдурахманов А.А., Коренев А.П. Административные договоры: понятие и виды // Журнал российского права. 1998. - №7. - С. 86.

7 См.: Демин А.В. Общие вопросы теории административного договора. - Красноярск. - 1998. - С.54.

См.: Бахрах Д.Н. Административное право России. - М., 2000. - C. 340 .
}

их органов; государственные органы при заключении и исполнении административного договора действуют в пределах своей компетенции; административный договор заключается в соответствии с административным актом; целью заключения административного договора являются публично-правовые интересы.

Заслуживают особого внимания критерии классификации административных договоров. В рамках данной статьи целесообразно остановиться на разделении административных договоров на нормативные и индивидуальные.

Нормативный административный договор имеет много общих черт с нормативным правовым актом. В юридической литературе нормативный административный договор называют договором о нормах. В данном случае нормативный договор определяется как «соглашение двух или более сторон, в результате которого устанавливаются, изменяются или отменяются нормы права» ${ }^{9}$. Таким образом, нормативный договор является источником права и представляет собой формально определенное соглашение, возникающее при согласовании свободных воль и волеизъявлений субъектов административного права, обладающих правотворческими полномочиями, устанавливающее административно-правовые нормы.

Индивидуальный административный договор также является формой государственного управления, выполняет общественно значимые задачи и служит достижению публичного интереса. Участники административного договора обладают лишь формальным равенством, а фактически зачастую один участник подчинен другому. Индивидуальный административный договор представляет собой соглашение двух или более субъектов административного права о возникновении, изменении или прекращении административных прав и обязанностей.

Учитывая природу права хозяйственного ведения и права оперативного управления, которые являются особыми имущественными правами, производными, зависимыми от прав собственника или ограниченными вещными правами ${ }^{10}$, логично предположить, что передача собственником государственного или муниципального имущества в хозяйственное ведение и оперативное управление государственным и муниципальным предприятиям и учреждениям осуществляется не по гражданско-правовым договорам в их клас-

\footnotetext{
9 См.: Лазарев В.В., Лепень С.В. Теория государства и права. - М., 2000. - С. 209.

10 См.: Российское гражданское право. Учебник: в 4 т. / под ред. Заслуженного деятеля науки РФ Е.А. Суханова. - М., 2011. - T. 1. - C. 606.
} 
сическом понимании. Право хозяйственного ведения и право оперативного управления возникают на основании акта собственника о закреплении имущества за государственным или муниципальным предприятием или учреждением.

Право публичной собственности в соответствии с российским законодательством подразделяется на право государственной и право муниципальной собственности. Публичное образование (государство, муниципалитет) является особым субъектом права в связи с наличием у него властных полномочий, в том числе, полномочия издавать административные акты в пределах своей компетенции.

Объектами права публичной собственности являются не только различные виды недвижимости, включая здания, сооружения, земельные участки, которые могут находиться в собственности и других субъектов, но и относящиеся исключительно к федеральной собственности ресурсы континентально шельфа, особо охраняемые природные территории, включая имущество государственных природных заповедников, национальные парки; памятники истории и культуры. В соответствии с Постановлением Верховного Совета РФ от 27 декабря 1991 г. № 3020-1 «О разграничении государственной собственности в Российской Федерации на федеральную собственность, государственную собственность республик в составе Российской Федерации, краев, областей, автономной области, автономных округов, городов Москвы и Санкт-Петербурга и муниципальную собственность» государственное имущество за исключением, имущества, отнесенного к муниципальной собственности (Приложение 3 к Постановлению), предполагается исключительно федеральным (Приложение 1 к Постановлению) или федеральным имуществом, которое может быть передано в собственность субъектов (Приложение 2 к Постановлению).

Не только государственное и муниципальное имущество, подлежащее передаче в хозяйственное ведение и оперативное управление, обладает особым правовым режимом, но и стороны договоров (актов) передачи государственного или муниципального имущества в хозяйственное ведение и оперативное управление также наделены специальным правовым статусом.

Права собственника государственного имущества, в том числе, право передачи его в хозяйственное ведение и оперативное управление осуществляют соответствующие органы исполнительной власти. Органом исполнительной власти, осуществляющим функции по управлению государственным имуществом, является Федеральное агентство по управлению государственным имуществом (Росимущество), которое находится в ведении Министерства экономического развития РФ. Росимущество осуществляет свою деятельность непосредственно и через свои территориальные органы и подведомственные организации во взаимодействии с другими федеральными органами исполнительной власти, органами исполнительной власти субъектов РФ, органами местного самоуправления. Федеральное агентство по управлению государственным имуществом осуществляет в порядке и в пределах, установленных федеральными законами, актами Президента РФ и Правительства РФ, полномочия собственника в отношении имущества федеральных государственных унитарных предприятий, федеральных государственных учреждений (п. 5.3. Положения о Федеральном агентстве по управлению государственным имуществом, утвержденном Постановлением Правительства РФ от 5 июня 2008 г. № 432). Министерства, Государственные корпорации также осуществляют права собственника в отношении федерального имущества, переданного государственным унитарным предприятиям, подведомственным им. В г. Москве управление имуществом осуществляет Департамент имущества г. Москвы, в Санкт-Петербурге - Комитет по управлению городским имуществом. Права собственника муниципального имущества, в том числе, право передачи его в хозяйственное ведение и оперативное управление осуществляют чаще всего Управления муниципального имущества.

В Положении о Федеральном агентстве по управлению государственным имуществом закреплены следующие полномочия Росимущества: осуществление контроля за управлением, распоряжением, использованием по назначению и сохранностью земельных участков, находящихся в федеральной собственности, иного федерального имущества, закрепленного в хозяйственном ведении или оперативном управлении федеральных государственных унитарных предприятий, федеральных государственных учреждений, а также переданного в установленном порядке иным лицам; при выявлении нарушений принятие мер по их устранению и привлечению виновных к ответственности (п. 5.8. Положения о Федеральном агентстве по управлению государственным имуществом). Росимущество наделяется также полномочиями по проведению в пределах своей компетенции проверок использования имущества, находящегося в федеральной собственности, ревизий, по принятию решений о проведении аудиторских проверок федеральных государственных унитарных предприятий, федеральных государственных учреждений (п. 5.10. Положения о Федеральном агентстве по управлению государственным имуществом). 
На Росимущество возложены такие полномочия в отношении федеральных государственных унитарных предприятий, как согласование с учетом предложений федерального органа исполнительной власти, в ведении которого находится федеральное государственное унитарное предприятие, сделок с недвижимым имуществом, закрепленным за предприятием на праве хозяйственного ведения (п. 5.17. Положения о Федеральном агентстве по управлению государственным имуществом); закрепление федерального имущества в хозяйственном ведении и оперативном управлении федеральных государственных унитарных предприятий и изъятие этого имущества в установленном порядке (п. 5.21. Положения о Федеральном агентстве по управлению государственным имуществом); закрепление федерального имущества в оперативном управлении федеральных государственных учреждений и изъятие излишнего, неиспользуемого или используемого не по назначению имущества (п. 5.22. Положения о Федеральном агентстве по управлению государственным имуществом).

Как мы видим, права собственника имущества и полномочия органа исполнительной власти по управлению государственным имуществом в отношении имущества, закрепленного в хозяйственном ведении и оперативном управлении федеральных государственных унитарных предприятий настолько широки, что права хозяйственного ведения и оперативного управления весьма условно можно отнести к вещным правам.

При этом собственник имущества, переданного в хозяйственное ведение и оперативное управление, в свою очередь, также ограничен в возможности распоряжения этим имуществом. Так в тексте Примерного договора аренды нежилого помещения, закрепленного на праве оперативного управления за государственным учреждением г. Москвы (Приложение к Постановлению Правительства Москвы от 29 января 2008 г. № 76-ПП «О порядке использования государственными учреждениями недвижимого имущества, переданного им в оперативное управление»), со стороны арендодателя выступают сразу два лица: Департамент имущества г. Москвы (либо его территориальное агентство) и Государственное учреждение г. Москвы; получателем арендной платы по договору аренды значится Департамент финансов г. Москвы (Департамент имущества г. Москвы).

В некоторых случаях, передав имущество в хозяйственное ведение унитарному предприятию, собственник не вправе распоряжаться таким имуществом независимо от наличия или отсутствия согласия предприятия. В соответствии ч. 11 ст. 154 Федерального закона от 22 августа 2004 г. № 122-Ф3 «О внесении изменений в законодательные акты Российской Федерации и признании утратившими силу некоторых законодательных актов Российской Федерации в связи с принятием федеральных законов «О внесении изменений и дополнений в Федеральный закон «Об общих принципах организации законодательных (представительных) и исполнительных органов государственной власти субъектов Российской Федерации» и «Об общих принципах организации местного самоуправления Российской Федерации» находящееся в собственности субъектов РФ имущество, закрепленное за государственными учреждениями и предприятиями, которое может находиться в федеральной собственности, в установленных законом случаях подлежит передаче в федеральную собственность только с согласия указанных предприятий и учреждений. В этом случае передаточный акт подписывается уполномоченным лицом предприятия или визируется уполномоченным лицом учреждения.

Таким образом, стороны договора о передаче имущества на праве хозяйственного ведения и праве оперативного управления являются субъектами административного права. Передает имущество орган исполнительной власти (его территориальное управление), государственный орган, например, Минобороны, Управление делами Президента РФ, Росимущество, на муниципальном уровне - управления муниципального имущества. Принимает имущество в хозяйственное ведение или оперативное управление государственное и муниципальные унитарное предприятия или государственное и муниципальное учреждение.

Гражданский кодекс РФ относит государственные и муниципальные унитарные предприятия наряду с хозяйственными товариществами и обществами к коммерческим организациям, т.е. организациям, преследующих извлечение прибыли в качестве основной своей цели. Однако, государственные и муниципальные унитарные предприятия, среди которых большинство составляют дирекции единого заказчика, ремонтно-эксплуатационные, сельскохозяйственные, экспертные предприятия не занимаются коммерческой деятельностью в той степени, как, например, акционерные общества. Основная цель их деятельности все же - публичные интересы. Еще одним признаком, характерным для административного договора, является публичный интерес.

Что касается государственных и муниципальных учреждений, особенно образовательных учреждений, музеев и библиотек, то о прибыли и вовсе говорить не приходится. Согласно ст. 120 Гражданского кодекса РФ учреждением является некоммерческая организация, созданная собственником для осуществления 
социально-культурных и иных функций некоммерческого характера, государственные и муниципальные учреждения в зависимости от целей их создания, меры ответственности по обязательствам, отношениям с собственником имущества подразделяются на казенные, автономные и бюджетные учреждения. Государственное и муниципальное имущество передается таким учреждениям для выполнения общественно-полезной задачи: научной, информационной, культурной, образовательной (предоставление в пользование юридическим и физическим лицам своих фондов, хранение, изучение, публичное представление музейных предметов и музейных коллекций). Государственные природные заповедники являются природоохранными, научно-исследовательскими и эколого-просветительными учреждениями, имеющими целью сохранение и изучение естественного хода природных процессов, генетического фонда растительного и животного мира. Здания, сооружения, историко-культурные и другие объекты недвижимости закрепляются за государственными природными заповедниками на праве оперативного управления (п. 2 ст. 6 Ф3 «Об особо охраняемых природных территориях»). В этих случаях необходимо отметить особый статус передаваемого имущества, поскольку речь идет о книжных памятниках, музейных предметах и музейных коллекциях, особо охраняемых природных территориях. Данные виды имущества подлежат охране независимо от того, в чьем ведении они находятся. Приняты нормативные акты, регулирующие правовое положение памятников истории и культуры, музеев и музейных коллекций, особо охраняемых природных территорий, библиотек, устанавливающие принципы формирования и ведения единых реестров, ограничений в пользовании, государственном контроле в области сохранения и использования данных объектов. Среди таких нормативных актов следует назвать Федеральный закон от 29 декабря 1994 г. № 78-Ф3 «О библиотечном деле», Федеральный закон от 14 марта 1995 г. № 33-Ф3 «Об особо охраняемых природных территориях», Федеральный закон от 26 мая 1996 г. № 54-Ф3 «О музейном фонде Российской Федерации и музеях в Российской Федерации», Федеральный закон от 25 июня 2002 г. № 73-Ф3 «Об объектах культурного наследия (памятниках истории и культуры) народов Российской Федерации», Постановление Правительства РФ от 31 декабря 2009 г. №1204 «Об утверждении Положения о государственном контроле в области сохранения, использования, популяризации и государственной охраны объектов культурного наследия (памятников истории и культуры) народов Российской Федерации», Приказ Министерства культуры РФ от 3 октября 2011 г. №954 «Об утверждении Положения о едином государственном реестре объектов культурного наследия (памятников истории и культуры) народов Российской Федерации». В этой связи уместно еще раз обратить внимание на то, что в этих случаях передается особо ценное, зачастую уникальное имущество - произведения живописи, скульптуры, памятники, ансамбли, книжные памятники, земля, водные объекты, недра, растительный и животный мир. Следует отметить ограничения пользования такими видами имущества, предусмотренные законодательством, а не только решением собственника имущества. Например, в соответствии со ст. 6 Ф3 «Об особо охраняемых природных территориях» природные ресурсы и недвижимое имущество государственных природных заповедников полностью изымаются из оборота, в соответствии со ст. 15 Ф3 «О музейном фонде Российской Федерации и музеях в Российской Федерации» музейные предметы и музейные коллекции, включенные в состав государственной части Музейного фонда РФ, не подлежат отчуждению, за исключением случаев утраты, повреждения либо обмена на другие музейные предметы и музейные коллекции, музейные коллекции неделимы; не подлежат приватизации государственные и муниципальные библиотеки, включая помещения и здания, в которых они расположены (ст. 23 Ф3 «О библиотечном деле»). Следует подчеркнуть, что библиотеки, как и вышеуказанные предприятия и учреждения, наделяются особым видом имущества - культурными ценностями, включая книжные памятники.

Как мы видим, другой стороной договора о передаче имущества на праве хозяйственного ведения и праве оперативного управления, принимающей имущество, является не любое юридическое лицо, а только государственное и муниципальные унитарное предприятия или государственное и муниципальное учреждение. Таким образом, следует отметить особый субъектный состав таких договоров.

Право хозяйственного ведения и право оперативного управления возникают на основании акта собственника о закреплении имущества за государственным или муниципальным предприятием или учреждением, что является признаком административного договора, но не гражданско-правового. Такой акт является разновидностью акта органов исполнительной власти или местного самоуправления: принимается в установленном порядке, имеет утвержденную форму, оспаривается в определенном порядке. Ранее имущество передавалось исполкомами учреждению на баланс приказом. Например, Соловецкому Государственному историко-архитектурному и природному музею-заповеднику приказом 
по Управлению культуры Архангельского облисполкома от 18 февраля 1975 г. за № 2539 памятников архитектуры были переданы на баланс согласно перечня с приложением акта определения балансовой стоимости памятников архитектуры Соловецких островов. Данным приказом музею предписывалось дать предложения по использованию памятников. Впоследствии Распоряжением Территориального управления Федерального агентства по управлению федеральным имуществом по Архангельской области данные объекты были закреплены на праве оперативного управления за Федеральным государственным учреждением культуры «Соловецкий государственный историко-архитектурный и природный музей-заповедник». На практике такими распоряжениями, изданными в соответствии с изменившимся законодательством, подтверждается передача имущества, которым учреждение или предприятие уже владеет многие годы. Аналогичным образом оформлялась передача имущества на праве хозяйственного ведения и праве оперативного управления не только музеям и библиотекам, но и предприятиям и учреждениям, подведомственным Российской Академии наук, в частности, научно-исследовательским институтам, образовательным учреждениям, которые приобрели статус государственных и муниципальных предприятий и учреждений. Такой порядок передачи имущества, подтверждающий административный, управленческих характер правоотношений по передаче государственного и муниципального имущества на праве хозяйственного ведения и оперативного управления, является законным и обоснованным, т.к. предприятия и учреждения фактически владеют этим имуществом на протяжении предшествующих десятилетий. Что касается памятников истории и культуры народов РФ, следует отметить еще и охранительную функцию органа исполнительной власти, осуществляющего государственный контроль в области сохранения, использования, популяризации и государственной охраны объектов культурного наследия. Таким образом, исполнение договоров о передаче памятников истории и культуры народов РФ учреждению на праве оперативного управления подвергается дополнительному контролю: объект передается по акту приема-передачи, принимающему имущество предприятию или учреждению предписано учесть имущество на балансе и принять меры по его охране.

Что касается формы договора о передаче имущества на праве хозяйственного ведения и праве оперативного управления, то она является типовой. Более того, типовая форма договора прилагается к решению собственника о передаче имущества ${ }^{11}$. Министерства приказом утверждают типовые договоры о передаче федерального имущества в оперативное управление и хозяйственное ведение ${ }^{12}$. На муниципальном уровне типовые договоры о закреплении имущества на праве хозяйственного ведения оперативного управления за муниципальным предприятием и учреждением утверждаются решением Думы ${ }^{13}$. Фактически при заключении таких договоров правило о свободе догово$\mathrm{pa}$, действующее при заключении гражданско-правовых договоров, не применяется.

Таким образом, отношения, возникающие между собственником имущества (публично-правовым образованием) и государственным и муниципальным унитарным предприятием или учреждением при передаче имущества на праве хозяйственного ведения и праве оперативного управления, имеют сложную правовую природу. Нельзя однозначно отрицать присущих этим отношениям гражданскоправовых признаков. Нормами гражданского права урегулированы такие положения договора о передаче имущества на праве хозяйственного ведения и праве оперативного управления, как положения о владении, пользовании, распоряжении переданным имуществом; об аренде переданного имущества c разрешения собственника; страховании; производстве ремонта имущества; возмещении ущерба. Однако наличие важнейших признаков, присущих административным договорам, правовая природа и цель заключения договоров о передаче имущества на праве хозяйственного ведения и праве оперативного управления позволяют отнести такой договор к административным договорам. Цель заключения договоров о передаче имущества на праве хозяйственного ведения и праве оперативного управления - прежде всего выполнение общественно значимых задач, т.е. публичный интерес. Стороны договора субъекты административного права: передающий имущество государственный орган (орган исполнительной власти, уполномоченный орган), орган местного самоуправления и принимающее имущество государственное и муниципальное унитарное

11 См.: Постановление Правительства Москвы от 29 июня 2010 г. №540-ПП «Об утверждении положения об управлении объектами нежилого фонда, находящимися в собственности города Москвы ».

12 См.: Приказ Главного управления исполнения наказаний Министерства юстиции РФ от 7 декабря 2001 г. №230 «Об утверждении Типовых договоров о передаче имущества в оперативное управление и хозяйственное ведение».

13 См.: Решение Думы Кировоградского городского округа Свердловской области от 25 января 2006 г. № 194. 
предприятие (учреждение). Стороны договора неравноправны: государственное и муниципальное унитарное предприятие или государственное и муниципальное учреждение юридически и фактически подчиняется соответствующему органу исполнительной власти, местного самоуправления, который наделен широкими полномочиями не только в отношении переданного имущества, но и в отношении самого предприятия или учреждения. Договор заключается на основании административного акта и имеет утвержденную административным актом типовую форму, т.е. регулируется административно-правовыми нормами. Передаваемое имущество зачастую обладает специальным статусом, охрана имущества осуществляется также при помощи административно-правовых норм. Таким образом, договор о передаче имущества на праве хозяйственного ведения и праве оперативного управления является особым видом административного договора. Право хозяйственного ведения и оперативного управления не отмирает, а напротив развивается, его формы, как и другие способы управления государственным и муниципальным имуществом постоянно совершенствуются, т.к. органы, уполномоченные управлять имуществом публично-правовых образований, по сравнению с 90-ми годами XX в. приобрели опыт такого управления, думается, что приходит осознание особой ценности и значимости государственного и муниципального имущества - экономической основы государства. Однако потребность в грамотных специалистах по управлению имуществом не удовлетворена. По-прежнему остро стоит вопрос о сохранности и рациональном использовании государственного и муниципального имущества. Представляется, что в тексте договора о передаче имущества на праве хозяйственного ведения и праве оперативного управления должны быть расширены и конкретизированы обязанности сторон по использованию государственного и муниципального имущества, по контролю за использованием и сохранностью имущества со стороны собственника имущества. В настоящее время собственник имущества, с одной стороны, и государственное, муниципальное предприятие и/или учреждение, с другой стороны, в процессе своей деятельности руководствуются множеством нормативных актов, судебной практикой, самостоятельным толкованием законодательства. Если их права и обязанности в отношении переданного в хозяйственное ведение и оперативное управление государственного и муниципального имущества, включая контрольные мероприятия, будут подробно изложены в тексте договора о передаче имущества, то стороны будут иметь четкое представление о пределах своих полномочий в отношении имущества уже в момент подписания договора. Это поможет в дальнейшем избежать споров между ними, в том числе, разрешаемых в судебном порядке.

\section{Библиографический список:}

1. Абдурахманов А.А., Коренев А.П. Административные договоры: понятие и виды // Журнал российского права. - 1998. - №7. - С. 86.

2. Административное право России / Под ред. А.П. Алехина. - М.: Зерцало, 2012.

3. Барциц И.Н. Реформа государственного управления в России. — М.: Формула права, 2007.

4. Бахрах Д.Н. Административные договоры. - М.: Административное право России, 2002.

5. Советское гражданское право. Учебник / под ред. В.П. Грибанова и С.М. Корнеева. - М.: Юридическая литература, 1980. Т. 2.

6. Демин А.В. Общие вопросы теории административного договора. — Красноярск, 1998. - С. 54.

7. Ждан-Пушкина Д.А. Новая судебная практика по спорам о праве собственности и иным вещным правам. М.: Проспект, 2008.

8. Лазарев В.В., Лепень С.В. Теория государства и права. — М., 2000. — С. 209.

9. Марченко М.Н. Источники права. Московский государственный университет им. М.В. Ломоносова. Юридический факультет. - М.: Проспект. 2011.

10. Новоселов В.И. К вопросу об административных договорах // Правоведение. — 1969. — №3.

11. Суханов Е.А. Понятие и виды ограниченных вещных прав // Вестник Московского университета. Серия 11. Право. - 2002. — №11.

12. Суханов Е.А. О понятиях и видах вещных прав в российском гражданском праве // Журнал российского права. - 2006. - №12.(120). - С. 42.

13. Российское гражданское право. Учебник: в 4 т. / Под ред. Е.А. Суханова. - М.: Статут, 2011.

14. Д.В. Петров. Право хозяйственного ведения и право оперативного управления - Монография: СПб., 2002. 


\section{References (transliteration):}

1. A.A. Abdurakhmanov.A.P. Korenev, Administrativnye dogovory: ponyatie i vidy// Zhurnal rossiyskogo prava. 1998. №7 -S.86

2. Administrativnoe pravo Rossii/ Pod red. A.P. Alekhina. - M.: Zertsalo, 2012.

3. I.N. Bartsits. Reforma gosudarstvennogo upravleniya v Rossii.- M.: Formula prava, 2007.

4. D.N. Bakhrakh. Administrativnye dogovory - M.: Administrativnoe pravo Rossii, 2002.

5. Sovetskoe grazhdanskoe pravo. Uchebnik pod red.: V.P. Gribanova i S.M. Korneeva. - M.: Yuridicheskaya literatura, 1980, t.2.

6. A.V. Demin. Obshchie voprosy teorii administrativnogo dogovora - Krasnoyarsk. — 1998. — S.54.

7. D.A.Zhdan-Pushkina. Novaya sudebnaya praktika po sporam o prave sobstvennosti i inym veshchnym pravam. M.: Prospekt, 2008.

8. V.V. Lazarev, S.V. Lepen'. Teoriya gosudarstva i prava. - M., 2000. — S.209.

9. M.N. Marchenko. Istochniki prava. Moskovskiy gosudarstvennyy universitet im. M.V. Lomonosova. Yuridicheskiy fakul'tet. - M.: Prospekt. - 2011.

10. V.I. Novoselov. K voprosu ob administrativnykh dogovorakh// Pravovedenie. — 1969. — №3.

11. E.A. Sukhanov. Ponyatie i vidy ogranichennykh veshchnykh prav// Vestnik Moskovskogo universiteta. Seriya 11. Pravo. - 2002. - №11.

12. E.A. Sukhanov. O ponyatiyakh i vidakh veshchnykh prav v rossiyskom grazhdanskom prave//Zhurnal rossiyskogo prava. 2006. №12.(120) - S. 42.

13. Rossiyskoe grazhdanskoe pravo. Uchebnik. V 4-kh tomakh. Pod red. E.A. Sukhanova. — M.: Statut, 2011.

14. D.V. Petrov. Pravo khozyaystvennogo vedeniya i pravo operativnogo upravleniya — Monografiya: Sankt-Peterburg, 2002.

15. Razgranichenie i privatizatsiya pamyatnikov istorii kul'tury kak put' sokhraneniya kul'turnogo naslediya Rossii (materialy parlamentskikh slushaniy Gosudarstvennoy Dumy FS RF.06.12.04) // Nedvizhimost' i investitsii. Pravovoe regulirovanie. Mart 2005. — №1(22). 